\title{
Concentrations of amino acids and urea in the plasma of the preruminant calf and estimation of the amino acid requirements
}

\author{
BY A. P. WILLIAMS AND R. H. SMITH \\ National Institute for Research in Dairying, Shinfield, Reading RG2 $9 A T$
}

(Received 30 fanuary I974-Accepted I7 May 1974)

\begin{abstract}
I. A study was made of factors affecting the plasma concentrations of free amino acids (PAA) and urea (PU) in calves receiving liquid diets.

2. When calves were given whole milk (approximately $0.05 \mathrm{~kg} / \mathrm{kg}$ live weight) at 10.00 and 17.00 hours there were marked decreases in PAA and slight decreases in PU for about $3-4 \mathrm{~h}$ after the morning feed. Both PAA and PU thereafter increased slightly and then remained constant for the next $10 \mathrm{~h}$. In subsequent comparative experiments samples were taken $3 \mathrm{~h}$ after the morning feed. The variation in plasma methionine, isoleucine, leucine, phenylalanine, tyrosine and total PAA was apparently greater between than within animals.

3. In calves transferred from a diet of whole milk to one consisting of diluted whole milk supplemented with appropriate nutrients, including amino acids, but deficient in methionine, PU increased markedly and plasma methionine decreased.

4. Two calves $(50-60 \mathrm{~kg}$ live weight) given the latter diet supplemented to give an intake of more than $4.5 \mathrm{~g} \mathrm{~L}$-methionine/d together with $0.3 \mathrm{~g}$ cystine/d showed marked increases in plasma methionine. This was considered to correspond with the point at which methionine requirements were met and that under these conditions the methionine requirement for these calves (mean value $\pm \mathrm{SE}$ ) was $4.5 \pm 0.2 \mathrm{~g} / \mathrm{d}$. In the same two calves PU decreased markedly with increasing levels of methionine supplementation up to $3.9 \mathrm{~g} / \mathrm{d}$ and the estimated methionine requirement (mean value $\pm \mathrm{SE}$ ) was $3.9 \pm 0.4 \mathrm{~g} / \mathrm{d}$.
\end{abstract}

Apart from the recent studies of Patureau-Mirand \& Pion (1973) and PatureauMirand, Prugnaud \& Pion (1973) there has been little work designed to study the amino acid requirements of the preruminant calf. This subject has recently achieved considerable practical importance with the increased interest in rearing calves, for long periods, on liquid diets containing considerable amounts of proteins less expensive than milk protein. Such alternative proteins may be deficient in some amino acids and particularly the sulphur amino acids and lysine. However, without a clear demonstration and quantitation of requirements for these amino acids the normal commercial practice of adding these amino acids to non-milk-protein substitutes to simulate the composition of cow's milk may be criticized on nutritional and economic grounds (Radostits \& Bell, 1970). Since the preruminant calf has been shown to be as dependent on its dietary supply of amino acids as simple-stomached animals (Blaxter \& Wood, 1952) it seemed likely that its amino acid requirements could be determined by methods used for such animals. Accordingly, changes in plasma amino acid (PAA) and plasma urea (PU) concentrations, in response to dietary supplementation, were measured to assess the amino acid status of the preruminant calf. Studies with chicks (Zimmerman \& Scott, 1965) and sows (Lewis \& Speer, I973) have shown that such measurements can give a valid assessment of amino acid requirements. Before the procedure was applied to the calf it was necessary to determine 
how PAA and PU concentrations were influenced by factors such as animal-toanimal variation (Iob, McMath \& Coon, 1963) and time of sampling after feeding (Porter \& Williams, 1963; Eggum, 1970) for there was little such information for the preruminant calf. A preliminary report of the work has been published (Williams \& Smith, 1973).

\section{EXPERIMENTAL}

\section{Animals and feeding}

A total of eighteen Friesian bull calves, aged between I and I 6 weeks, was used. All newborn calves were reared for $2 \mathrm{~d}$ on colostrum and thereafter on a whole-milk diet given at a rate (approximately $0.05 \mathrm{~kg} / \mathrm{kg}$ live weight) sufficient to maintain an increase in body-weight of about $0.25 \mathrm{~kg} / \mathrm{d}$ (Roy, Shillam, Hawkins \& Lang, 1958). The milk given to calves over 3 weeks of age was supplemented with iron, manganese, copper, magnesium, retinol, $\alpha$-tocopherol and cholecalciferol (Coombe \& Smith, 1973).

Effect of time of sampling after feeding. Four calves were given equal amounts of the whole-milk diet twice daily at 10.00 and 17.00 hours. Samples of jugular blood were taken from each animal at $35 \mathrm{~d}$ of age and at 10.00, I I.00, 12.00, 13.00, 14.00, 15.00 , 16.00, 18.00, 20.00, 22.00, 24.00,02.00, 04.00, 06.00, 08.00 and 10.00 hours.

Variation between and within animals at different ages. Jugular blood samples were taken at 13.00 hours from calves given equal amounts of whole milk twice daily at I0.00 and 17.00 hours. Such samples were taken from ten calves at 5 weeks of age and from two calves at weekly or 2-weekly intervals between 2 and 9 weeks of age.

Methionine requirements. From $35 \mathrm{~d}$ of age two calves were given successively, for periods of I week, diets in the order: whole milk, synthetic milk with supplements of o, $0.8,1 \cdot 6,2.4,3 \cdot 2,4.0,4.8$ and $6.4 \mathrm{~g} \mathrm{~L}$-methionine/d, whole milk and unsupplemented synthetic milk. Both the whole milk and the synthetic milk were given in equal amounts twice daily at 10.00 and 17.00 hours in amounts (approximately $0.05 \mathrm{~kg} / \mathrm{kg}$ live weight) sufficient to maintain an increase in body-weight of about $0.25 \mathrm{~kg} / \mathrm{d}$ (Roy et al. 1958). Jugular blood samples were taken from each calf at I3.00 hours on the last day of each period. Each $\mathrm{kg}$ of synthetic milk contained $0.25 \mathrm{~kg}$ whole milk, $0.53 \mathrm{~kg}$ synthetic milk similar to that described by Smith (1959), except that casein was omitted, and $210 \mathrm{ml}$ of an aqueous solution containing the following amino acids $(\mathrm{g})$ : asparagine $2 \cdot 6_{3}$, threonine $\mathrm{I} \cdot \mathrm{I} \mathrm{I}$, serine $0 \cdot 74$, glutamine $6 \cdot 84$, proline $I \cdot 10$, glycine 0.47 , alanine $0 \cdot 79$, valine $I \cdot 58$, isoleucine $I \cdot 42$, leucine $2 \cdot 32$, tyrosine $I \cdot 2 \mathrm{I}$, phenylalanine $\mathrm{I} \cdot \mathrm{I} 6$, lysine $\mathrm{I} \cdot 8 \mathrm{~g}$, histidine 0.63 , arginine 0.84 and tryptophan 0.32 . Whole milk was included to retain some clotting characteristics. To each synthetic diet, mineral solutions A, B and C (Coombe \& Smith, 1973) were added, at levels of $24,4^{2}$ and $22 \mathrm{ml} / \mathrm{kg}$ diet respectively. The amino acid, milk and mineral components of the synthetic diets were mixed just before feeding and the whole mixture homogenized for 5 min using a Silverson homogenizer (Model AX; Silverson Machines, London SE I). Amino acids were obtained from SAS Scientific Chemicals Ltd, London and the $\mathrm{L}$-forms were used throughout. 


\section{Sampling of blood}

Blood samples were taken through a $150 \mathrm{~mm}$ nylon cannula (Portex nylon tubing: size $3 \mathrm{v}$, i.d. $\mathrm{I} \cdot 0 \mathrm{~mm}$; Portex Ltd, Hythe, Kent) inserted into the jugular vein at least $30 \mathrm{~min}$ before feeding. Blood samples (ro $\mathrm{ml}$ ) were collected directly into centrifuge tubes containing $5^{\circ}$ I.U. heparin (Boots Ltd, Nottingham) and were centrifuged for $30 \mathrm{~min}$ at $125^{\circ} \mathrm{g}$ and at $4^{\circ}$. Part of the separated plasma was stored at $-20^{\circ}$ for urea, nitrogen analysis. The remainder was deproteinized with I.22 vol. 0.47 M-sulphosalicylic acid containing $0.18 \mu \mathrm{mol} \mathrm{L}-\alpha$-amino- $\beta$-guanidino-propionic acid (Calbiochem Ltd, London) $/ \mathrm{ml}$ and the supernatant fraction stored at $-20^{\circ}$ for amino acid analysis. The $\mathrm{L}-\alpha$-amino- $\beta$-guanidino-propionic acid was added as an internal standard to correct for losses of amino acid during deproteinization of the plasma.

\section{Analytical methods}

Milk. Total $\mathrm{N}$ was determined by a micro-Kjeldahl method (Smith \& McAllan, 1970). Most amino acids were determined after hydrolysis with $6 \mathrm{M}-\mathrm{HCl}$ at $110^{\circ}$ for $24 \mathrm{~h}$, by the method of Spackman, Stein \& Moore (1958), but cystine and methionine were determined by the method of Moore (1963). Either a JLC-5AH (Jeolco, Tokyo) or a multichannel (Evans Electroselenium Ltd, Halstead, Essex) amino acid analyser was used for amino acid analysis.

Blood plasma. The free amino acids in blood plasma samples were determined by the method of Spackman et al. (1958) using the multichannel amino acid analyser (EEL, Halstead, Essex). The concentrations of tryptophan and proline in calf plasma were too low for estimation under our conditions. Urea- $\mathrm{N}$ was estimated using a Technicon AutoAnalyzer (Technicon Instruments Co. Ltd, Basingstoke) using the method of Technicon Instruments Corp. (1967). A dialyser was incorporated into the AutoAnalyzer so that it was unnecessary to deproteinize the plasma chemically.

\section{RESULTS}

\section{Factors affecting plasma composition}

Time of sampling. The amino acid and urea concentrations in the jugular blood plasma of four calves (given cow's milk) at various times during a $24 \mathrm{~h}$ period are shown in Fig. I. After the morning feed there was a small decrease in PU concentrations and a larger decrease in total PAA concentrations between ro.00 hours and I3.00-14.00 hours, followed, in the instance of PU, by a slight increase between I 4.00 and 16.00 hours. There was no marked change in PU or total PAA concentrations after the evening feed. Most individual amino acids showed similar patterns of change to that of the total PAA. In subsequent comparative experiments blood samples were taken at 13.00 hours.

Variation between and within animals. The PAA and PU concentrations of calves given cow's milk are given in Table $\mathrm{I}$. Results for two calves sampled at weekly or 2-weekly intervals between 2 and 9 weeks of age (two calves, $50-65 \mathrm{~kg}$ live weight) showed that the variation in plasma methionine, isoleucine, leucine, phenylalanine, 

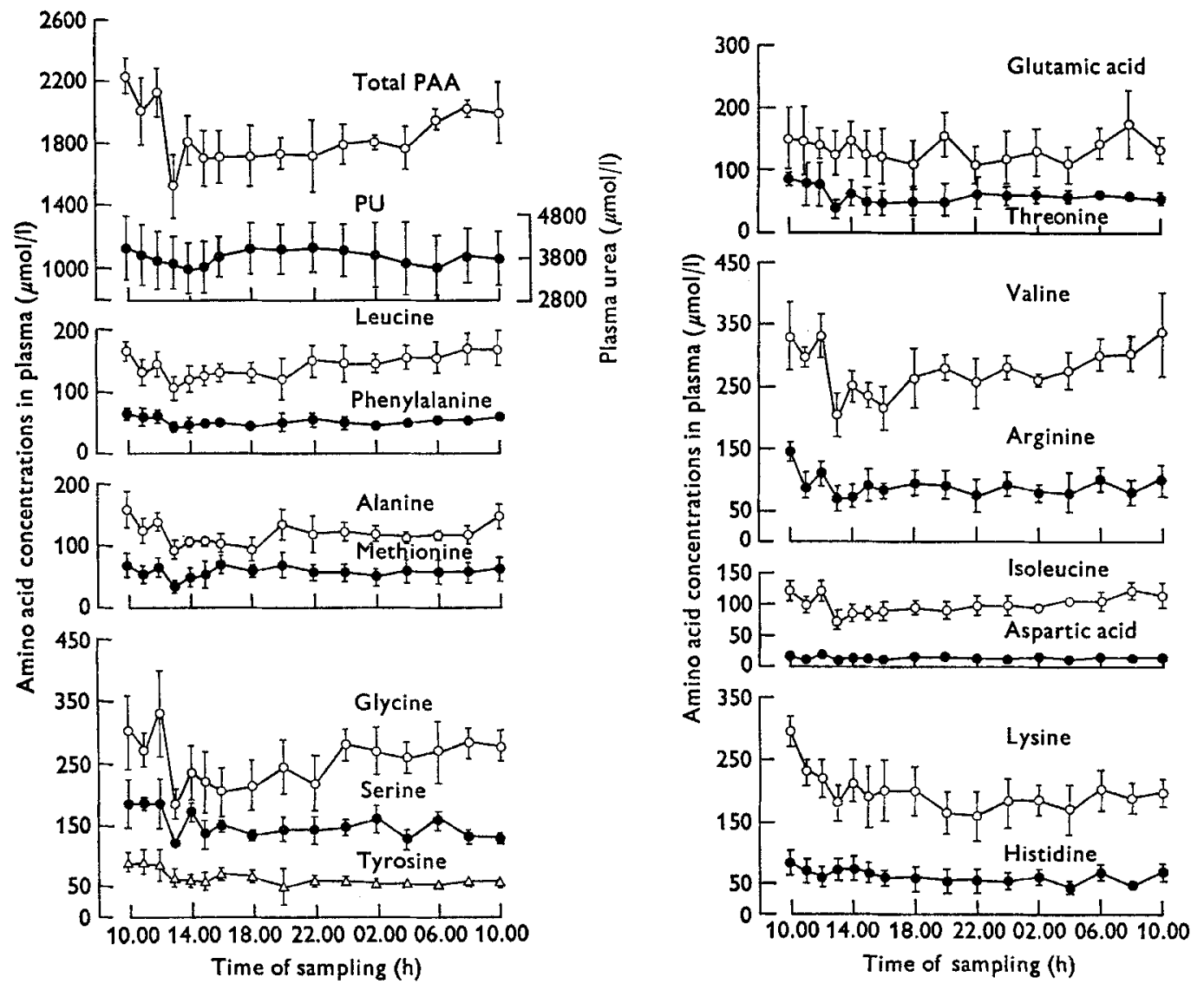

Fig. 1. Effect of time of sampling relative to food ingestion on amino acids (PAA) and urea (PU) concentrations in the jugular blood of calves given equal amounts of milk at 10.00 and $\mathrm{I} 7.00$ hours. Mean values for four animals; vertical bars represent the standard errors of the mean.

tyrosine and total PAA concentrations was significantly or nearly significantly greater between than within animals. PU, individual and total PAA concentrations in individual samples from ten calves at 5 weeks of age (mean live weight $\pm \mathrm{SE}, 5 \mathrm{I} \pm \mathrm{I} \cdot 4$ $\mathrm{kg}$ ) also showed very wide between animal variations. Little variation with age was apparent in PU and PAA concentrations (Fig. 2) and within any one animal, background variation appeared sufficiently low to permit satisfactory interpretation of changes (or lack of changes) induced by dietary changes.

Methionine requirements. No significant difference was found between the values for PAA and PU obtained at the start and finish of each series of treatments with whole milk and the unsupplemented synthetic diet. For example, the plasma methionine concentrations for two calves (mean values $\pm \mathrm{SE}$ ) given milk were $38 \cdot 9 \pm 4.9$ and $47.8 \pm 0.8 \mu \mathrm{mol} / 1$ for the pre- and post-treatment samples respectively; corresponding PU concentrations were $3784 \pm 500$ and $3677 \pm 393 \mu \mathrm{mol} / 1$ respectively. For the same two calves given the unsupplemented synthetic diet the plasma methionine 
Table I. Variation between and within calves in the concentrations of amino acids $(P A A)(\mu m o l / l)$ and urea ( $\mu \mathrm{mol} / \mathrm{l})$ in the jugular blood plasma 3 h after a meal of cow's milk

No. of calves $\quad \ldots$

2

IO

Ages (weeks) when each calf was sampled ...

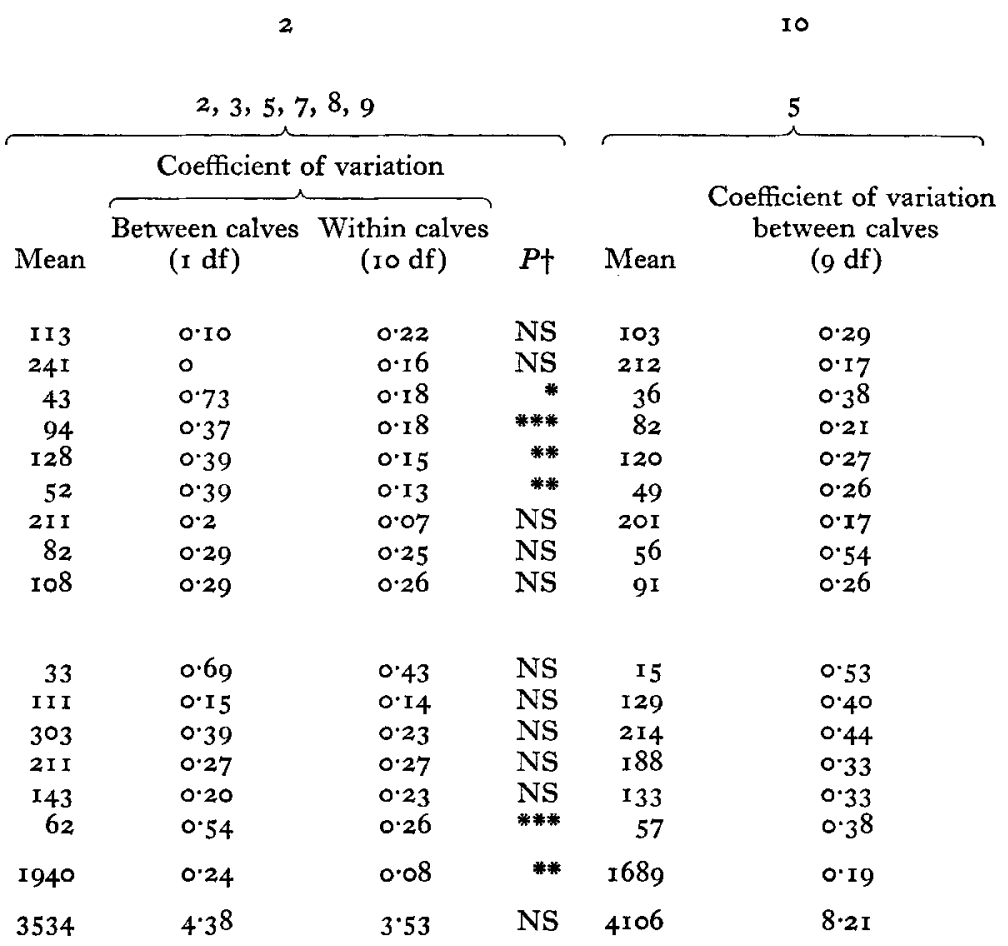

Essential amino acids

Threonine

Valine

Methionine

Isoleucine

Leucine

Phenylalanine

Lysinet.

Histidine

Arginine

Non-essential amino acids

Aspartic acid

Serine§

Glutamic acid

Glycine

Alanine

Tyrosine

Total PAA

Urea

s

Significance levels: NS, $P>0.1 ; * P \leqslant 0.01 ; * * P \leqslant 0.05 ; * * * P \leqslant 0.1$.

$\dagger$ Probability that the variation between calf means for calves sampled on six occasions is greater than the variation between sampling times within calves.
Includes ornithine.
$\S$ Includes glutamine and asparagine.

concentrations (mean values $\pm \mathrm{SE}$ ) were $19.0 \pm \mathrm{I} \cdot \mathrm{O}$ and $18.5 \pm 2.5 \mu \mathrm{mol} / 1$ for the preand post-treatment samples respectively; corresponding PU concentrations were $5747 \pm 214$ and $5569 \pm 179 \mu \mathrm{mol} / \mathrm{l}$ respectively. These results suggest that plasma methionine and urea were not affected by time. Thus the effects of varying the level of methionine in the diet (described below) may therefore be assumed the true effects of methionine despite the non-random distribution of treatments with respect to time.

PU concentrations in the two calves increased markedly from $3784 \pm 500$ to $5747 \pm$ 2 I $4 \mu \mathrm{mol} / 1$ when the semi-synthetic diet simulating milk, but deficient in methionine, was given instead of cow's milk. Supplementation of the deficient diet with methionine led to a marked fall in PU when the supplements were small, but showed little response to increasing amounts of supplementary methionine when the supplements were large (Fig. $3 a$ ).

Two regression equations were calculated, one for levels of dietary methionine considered to be below the requirement and one for levels above the requirement. 

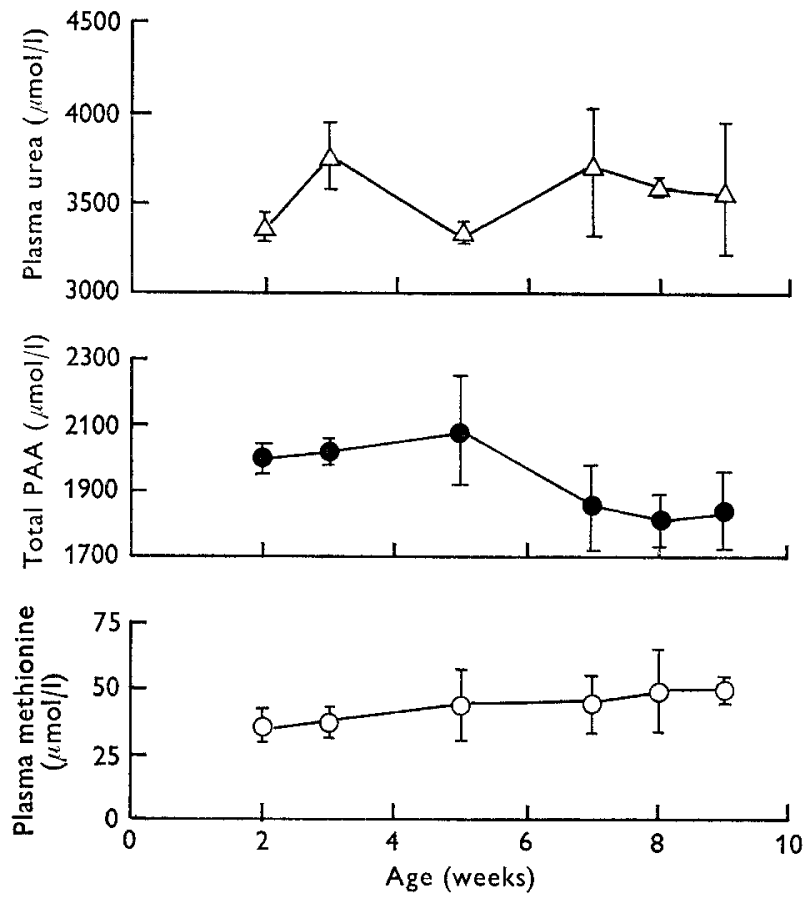

Fig. 2. Effect of age on plasma methionine $(\mathrm{O}-\mathrm{O})$; total plasma amino acid (PAA) (-); and plasma urea $(\triangle-\triangle)$ concentrations in the jugular blood of calves given whole milk. Mean values for two animals; vertical bars represent the standard errors of the mean. Samples were taken $3 \mathrm{~h}$ after the morning feed.
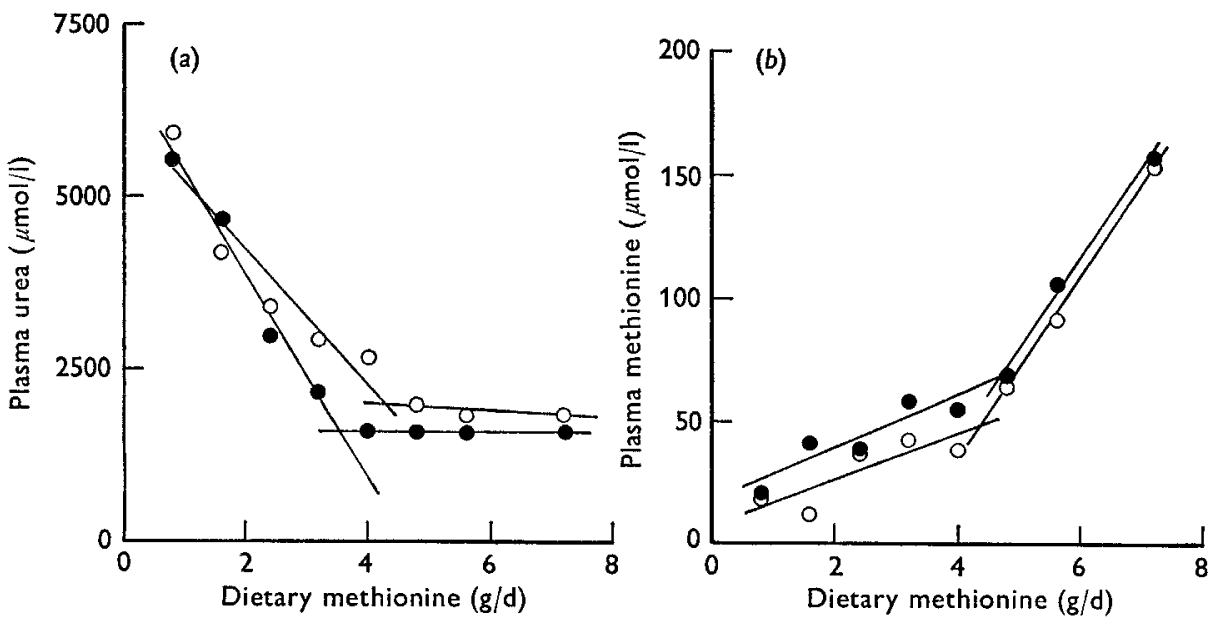

Fig. 3. Effect of dietary methionine supplementation on (a) plasma urea and (b) plasma methionine concentrations in the jugular blood of the calf. Values are given for two experiments with individual calves; calf $30 \mathrm{I}(\mathrm{O}-\mathrm{O})$; calf $35 \mathrm{I}(-\mathrm{O})$. Samples were taken $3 \mathrm{~h}$ after the morning feed. 
The linear regressions of $\mathrm{PU}\left(y_{1}\right) v$. methionine in the diet $(\mathrm{g} / \mathrm{d})$, below $\left(x_{D}\right)$ and above $\left(x_{E}\right)$ the requirement were:

$$
\begin{aligned}
& \text { calf } 3 \text { or: } y_{1}=6165-968 * x_{D} \text { (residual SD 500, } 3 \mathrm{df} \text { ); } \\
& y_{1}=2203-5^{\mathrm{NS}} x_{E} \text { (residual sD } 7 \mathrm{I}, \mathrm{I} \mathrm{df} \text { ), } \\
& \text { calf } 35 \text { I : } y_{1}=6765^{-1} 464^{* *} x_{D} \text { (residual SD 250, } 2 \mathrm{df} \text { ); } \\
& y_{1}=1607 \pm 0 x_{E} \text { (residual SD } 0,2 \mathrm{df} \text { ) }
\end{aligned}
$$

(significance levels: NS, $P>0.05 ; * P \leqslant 0.05 ; * * P \leqslant 0.01$ ). The point of intersection of the two regression lines was taken to be an estimate of the requirement. The methionine requirements for the two calves $(P \leqslant 0.05)$ were $4 \cdot 2(3 \cdot 1,4 \cdot 8)$ and $3 \cdot 5(3 \cdot 0,4 \cdot 7) \mathrm{g} / \mathrm{d}$ for calves 3 or and $35 \mathrm{I}$ respectively.

In the same two calves plasma methionine concentrations fell markedly from $38.9 \pm 4.9$ to $19 \cdot 0 \pm \mathrm{I} \cdot \circ \mu \mathrm{mol} / \mathrm{l}$ when the animals were given the methionine-deficient diet instead of milk. Increasing methionine supplements had little effect on plasma methionine when the supplements were small, but caused plasma methionine to increase markedly when the supplements were large (Fig. $3 b$ ). Two regression equations were calculated, one for levels of dietary methionine considered to be below the requirement and one for levels above the requirement. The linear regressions of plasma methionine $\left(y_{2}\right)$ on methionine in the diet $(\mathrm{g} / \mathrm{d})$, below $\left(x_{D}\right)$ and above $\left(x_{E}\right)$ the requirement were:

$$
\begin{aligned}
& \text { calf } 30 \mathrm{I}: y_{2}=8 \cdot \mathrm{I}+9 \cdot 0^{* * *} x_{D} \text { (residual sD 8.7, } 3 \mathrm{df} \text { ); } \\
& \left.y_{2}=-116 \cdot 0+37 \cdot 5^{*} x_{E} \text { (residual SD } 2 \cdot 2, \mathrm{I} \mathrm{df}\right), \\
& \text { calf } 35 \mathrm{r}: y_{2}=\mathrm{I} 7 \cdot \mathrm{I}+\mathrm{I0} \cdot 9^{*} x_{D} \text { (residual sD } 7 \cdot 7,3 \mathrm{df} \text { ); } \\
& y_{2}=- \text { IOI } \cdot 8+36 \cdot 3 * * x_{E}(\text { residual SD } 6 \cdot 7, \mathrm{r} \text { df) }
\end{aligned}
$$

(significance levels: $* P \leqslant 0.05, * * P \leqslant 0.1$ ).

From the point of intersection of the two regression lines the estimated methionine requirements for the two calves $(P \leqslant 0.05)$, were $4.4(3 . \mathrm{I}, 4.8)$ and $4.7(3.5,5 . \mathrm{I}) \mathrm{g} / \mathrm{d}$ for calves 301 and 351 respectively.

\section{DISCUSSION}

The findings, that calves given milk showed decreases in PAA and PU concentrations soon after the morning feed, are in contrast to the usual changes in simplestomached animals. For these animals it has often been shown (Munro, 1970; Porter \& Rolls, 197I) that there is an increase in PAA and PU concentrations between 0 and $3 \mathrm{~h}$ after a meal containing protein. Patureau-Mirand, Prugnaud \& Pion (I97I) also found, for calves given milk, that the concentrations of most individual PAA decreased after feeding and both they and Nitsan, Volcani, Gordin \& Hasdai (I97I) observed decreases in PU at this time, although to different extents. The reasons for responses in PAA and PU concentrations in the preruminant calf being different from those in other simple-stomached animals are not yet clear although they may be related to the fairly slow and uniform flow of $\mathrm{N}$ compounds from the abomasum to the duodenum after a calf is given a milk feed (Mylrea, 1966). Patureau-Mirand et al. 
(197I) found that calves given synthetic diets containing proteins which did not form a clot in the abomasum, showed a different pattern of PAA response with time after feeding, compared with calves given milk. However, neither Patureau-Mirand et al. (1971) nor Nitsan et al. (197I) found any appreciable differences in PU responses with time after feeding due to such dietary differences.

Our findings of considerable between-animal variation in PU and PAA concentrations are in agreement with those of Boling, Bradley \& Willard (1972), Reece \& Wahlstrom (1972) and Thornton, Butler \& Willoughby (1973).

Results for the effects of age on total PAA concentrations (Fig. 2) indicated that between 2 and 9 weeks little change occurred. The same was generally true for the individual amino acids although this is shown only for methionine in Fig. 2. The decreases in most of the individual plasma amino acids of the calf found by Leibholz (1965) between birth and 4 weeks of age occurred mainly in the first 2 weeks. Many other species have been found to show a decrease in PAA concentrations in the first few weeks after birth (Munro, 1970).

Although there were some differences in the proportions of individual amino acids present the mean value for total concentrations of PAA established in milk-fed calves older than 2 weeks $(1689 \mu \mathrm{mol} / 1)$ was similar to that found $(1925 \mu \mathrm{mol} / \mathrm{l})$ for ruminating calves aged 16 weeks and receiving different diets (Williams \& Smith, 1974). Concentrations of PU on the other hand differed greatly between the different groups of animals and between preruminant calves given liquid diets of differing amino acid composition. This was seen both in the present experiments and in calves transferred from milk to diets which were tryptophan-deficient (Williams \& Smith, 1973). As in other species PU concentrations in the calf depend greatly on the diet. When a constant diet of cow's milk was given then our findings (Fig. 2) agreed with those of Reece \& Wahlstrom (1972) and of Thornton et al. (1973) in showing little change in PU concentrations with age. Leibholz (1965) found considerable variation in PU concentrations with age for calves up to 4 weeks of age. Only the results of Nitsan, Volcani, Hasdai \& Gordin (1972) showed a fall in PU with age for the calf, similar to that shown by other species (Munro, 1970).

The estimated methionine requirements for the preruminant calf, mean values ( \pm SE, with $\mathrm{I} d \mathrm{df}$ ), based upon responses to dietary methionine supplementation of either plasma methionine or PU concentrations were $4.5 \pm 0.2$ and $3.9 \pm 0.4 \mathrm{~g} / \mathrm{d}$ respectively. Each of these methods of estimating amino acid requirements has been shown for other species (Zimmerman \& Scott, I965; Lewis \& Speer, 1973) to give a value which corresponds to an intake of the amino acid at which maximum $\mathrm{N}$ retention and growth are attained. The agreement between results from the two methods supports the view that this is true also for the calf although no direct examination of responses in animal performance was made. It should be recognized, however, that the values obtained for the methionine requirement are for the particular conditions studied (calves with a live weight of $50-60 \mathrm{~kg}$ growing at about $0.25 \mathrm{~kg} / \mathrm{d}$ and receiving a cystine intake of $0.3 \mathrm{~g} / \mathrm{d}$ ) and care should be taken in reaching general conclusions. It seems probable that the cystine requirement of the calf is greater than $0.3 \mathrm{~g} / \mathrm{d}$. No direct information is available, but in the pig it is assumed 
that cystine can contribute about half the $\mathrm{S}$ amino acid requirements (see Agricultural Research Council, I967). If this is so, part of the methionine received by our calves must have been used to supply cystine requirements and it is reasonable to conclude that the total requirement for $S$ amino acids was about $4 \cdot 2-4.8 \mathrm{~g} / \mathrm{d}$ or expressed in terms of metabolic body-weight $\left(\mathrm{W}^{0.73}\right.$ ), about $0.23-0.26 \mathrm{~g} / \mathrm{kg} \mathrm{W}^{0.73}$ per $\mathrm{d}$. This value is consistent with that $\left(0.4 \mathrm{I} / \mathrm{g} / \mathrm{kg} \mathrm{W}^{0.73}\right.$ per $\left.\mathrm{d}\right)$ which may be derived from the results of Williams \& Smith (1974) for the total S amino acid requirements of ruminating calves weighing IIO-II6 kg and growing at a rate of $0.4 \mathrm{~kg} / \mathrm{d}$. However, the latter requirement may be over-estimated as cystine supply may have exceeded cystine requirements. The amount of milk required to support a growth rate of $0.25 \mathrm{~kg} / \mathrm{d}$ in calves weighing $50-60 \mathrm{~kg}$ would provide $3.2 \mathrm{~g}$ methionine/d and $\mathrm{I} \cdot \mathrm{g}$ cystine/d. This is close to our estimate of the total $\mathrm{S}$ amino acid requirement and, under these conditions, cow's milk provides no surplus of $S$ amino acids. A comparable synthetic diet in which isolated soya-bean protein replaced milk protein would supply only $\mathrm{r} \cdot 3 \mathrm{~g}$ methionine and $\mathrm{r} \cdot 4 \mathrm{~g}$ cystine and might be markedly deficient in $\mathrm{S}$ amino acids. Supplementation with methionine of a liquid diet containing isolated soya-bean protein as the only protein source was reported to improve $\mathrm{N}$ retention of calves (Porter \& Hill, I964), but no determination of the optimum amounts required was made. The only other work providing a quantitative estimate of methionine requirements for the preruminant calf is that of PatureauMirand \& Pion (1973) and Patureau-Mirand et al. (1973) who studied the response in plasma methionine concentrations to supplementation of milk-protein diets with graded amounts of methionine. Their estimate of methionine requirement $\left(0.5^{8} \mathrm{~g} / \mathrm{kg}\right.$ $\mathrm{W}^{\mathbf{0} .73}$ per d) was much greater than our results in these experiments and corresponded to a probable requirement for total $\mathrm{S}$ amino acids (calculated from estimated values for their diets; no results for cystine intakes were given) of about $0.66 \mathrm{~g} / \mathrm{kg}$ $\mathrm{W}^{\mathbf{0} \cdot 73}$ per $\mathrm{d}$. It is possible that their very high value was related to the rapid growth of their calves (about $\mathrm{I} \cdot \mathrm{kg} / \mathrm{d}$ ), but more information to explain the apparent discrepancies is required.

We thank Mrs S. J. Askew for supervising the care of the animals, Mr J. E. Cockburn for carrying out amino acid analyses and Mrs D. J. Faulder for technical assistance. We also wish to thank Dr D. Hewitt for help with the statistical analyses.

\section{REFERENCES}

Agricultural Research Council (1967). The Nutrient Requiremento f Farm Livestock No. 3, Pigs. London: Agricultural Research Council.

Blaxter, K. L. \& Wood, W. A. (1952). Br. Y. Nutr. 6, 56 .

Boling, J. A., Bradley, N. W. \& Willard, J. C. (1972). Int. Z. VitamForsch. 42, 306.

Coombe, N. B. \& Smith, R. H. (1973). Br. F. Nutr. 30, 33I.

Eggum, B. O. (1970). Br. F. Nutr. 24, 983.

Iob, V., McMath, M. \& Coon, W. C. (1963). F. surg. Res. 3, 85 .

Leibholz, J. (1965). Aust. F. agric. Res. 16, 973.

Lewis, A. J. \& Speer, V. C. (1973). F. Anim. Sci. 37, 104.

Moore, S. (1963). F. biol. Chem. 238, 235.

Munro, H. M. (1970). In Mammalian Protein Metabolism Vol. 4, p. 299 [H. N. Munro, editor]. New York: Academic Press. 
Mylrea, P. J. (1966). Res. vet. Sci. 7, 394.

Nitsan, Z., Volcani, R., Gordin, S. \& Hasdai, A. (1971). F. Dairy Sci. 54, 1294.

Nitsan, Z., Volcani, R., Hasdai, A. \& Gordin, S. (1972). F. Dairy Sci. 55, 8 I 1.

Patureau-Mirand, P. \& Pion, R. (1973). Proc. Eur. Nutr. Conf., Cambridge, I973.

Patureau-Mirand, P., Prugnaud, J. \& Pion, R. (197 r). Proc. Ioth int. Congr. Anim. Prod., Versailles.

Patureau-Mirand, P., Prugnaud, J. \& Pion, R. (1973). Annls Biol. anim. Biochim. Biophys. 13, 225.

Porter, J. W. G. \& Hill, W. B. (1964). A. Rep. natn. Inst. Res. Dairy. p. 124.

Porter, J. W. G. \& Rolls, B. A. (I97I). Proc. Nutr. Soc. 30, I7.

Porter, J. W. G. \& Williams, A. P. (1963). Biochem. F. 87, 7 P.

Radostits, O. M. \& Bell, J. M. (1970). Can. F. Anim. Sci. 50, 405.

Reece, W. O. \& Wahlstrom, J. D. (1972). Am. J. vet. Res. 33, 2175.

Roy, J. H. B., Shillam, K. W. G., Hawkins, G. M. \& Lang, J. M. (1958). Br. F. Nutr. I2, 123.

Smith, R. H. (1959). Biochem. F. 71, 306 .

Smith, R. H. \& McAllan, A. B. (1970). Br. F. Nutr. 24, 545.

Spackman, D. H., Stein, W. H. \& Moore, S. (1958). Analyt. Chem. 30, I 190.

Technicon Instruments Corp. ( I 967). Technicon Method Sheet N-IC. Tarrytown, New York: Technicon Instruments Corp.

Thornton, J. R., Butler, D. G. \& Willoughby, R. A. (1973). Aust. vet. F. 49, 20.

Williams, A. P. \& Smith, R. H. (1973). Proc. Nutr. Soc. 32, 52A.

Williams, A. P. \& Smith, R. H. (1974). Proc. Nutr. Soc. 33, 35A.

Zimmerman, R. A. \& Scott, H. M. (1965). F. Nutr. 87, I3. 